\title{
Spinal neurenteric cysts and their relation to more common aspects of occult spinal dysraphism
}

\author{
Michael J. Rauzzino, M.D., R. Shane Tubbs, M.S., P.A.-C., Eben AleXander, III, M.D., \\ Paul A. Grabi, M.D., and W. Jerry OAKes, M.D. \\ Peninsula Neurosurgical Associates, Hampton, Virginia; Brigham and Women's Hospital, Boston, \\ Massachusetts; and Section of Pediatric Neurosurgery, Division of Neurological Surgery, Department \\ of Surgery, University of Alabama at Birmingham, Alabama
}

\begin{abstract}
Object. Neurenteric cysts are infrequently reported congenital abnormalities believed to be derived from an abnormal connection between the primitive endoderm and ectoderm. The authors report a series of 13 patients treated over a 50 -year period.

Methods. Of the 13 patients, seven were female and six were male. Their ages at presentation ranged widely from 5 weeks to 52 years of age. Children presented more commonly with cutaneous stigmata of occult spinal dysraphism (OSD) whereas adults presented primarily with pain. Neurological deficit as a presenting symptom was less common in our series, a finding that reflects the slow growth of these lesions. In all but one patient some form of vertebral anomaly was associated with the cystic lesions, including two patients with Klippel-Feil abnormalities. There was a high incidence of associated forms of OSD including split cord malformation, lipoma, dermal sinus tract, and tethered spinal cord. In previous reports the authors have suggested that neurenteric cysts are more common in the cervical region and in a position ventral to the cord. In the present series these cysts most commonly occurred as intradural, extramedullary masses in the thoracolumbar region, situated dorsal to the spinal cord. The median follow-up period was 7.5 years, and postoperative outcome reflected a patient's preoperative neurological status; in no patient was outcome worsened due to surgery.

Conclusions. Complete excision of the neurenteric cyst remains the treatment of choice, as subtotal excision is associated with recurrence.
\end{abstract}

\section{KEY WORDS - neurenteric cyst - occult spinal dysraphism}

Spinal neurenteric cysts are infrequently reported congenital abnormalities believed to be derived from an abnormal connection between the primitive endoderm and ectoderm during the 3rd week of life. Neurenteric cysts are not confined to the spinal column but may be found within the brain, mediastinum, abdomen, pelvis, or even in a subcutaneous location. ${ }^{1,3,16,17,28,48,50}$ These lesions are rare. Intraspinal neurenteric cysts represent 0.3 to $0.5 \%$ of all spinal "tumors." 35 They are, in fact, not tumors, which differentiates them from teratomas; instead, they are more similar to harmatomas-displaced nests of endodermally derived tissue. The terminology for these lesions is problematic, as they have been reported as a neurenteric cyst, enterogenous cyst, enteric cyst, gastrocytoma, dorsal enteric fistula, split notochord syndrome, and teratoid cyst. $6,12,20,26,27,37,49$ Part of the confusion in naming these cysts is that they are not uniform; likely they exist as a spectrum of lesions. The presentation may vary from a simple isolated intraspinal cyst with no other abnormali-

Abbreviations used in this paper: $\mathrm{CT}=$ computerized tomography; $\mathrm{MR}=$ magnetic resonance; OSD = occult spinal dysraphism; $\mathrm{SCM}=$ split cord malformation; $\mathrm{VB}=$ vertebral body. ties to that of the so-called split notochord syndrome, as proposed by Bentley and Smith $^{6}$ in which there may be multiple visceral and vertebral anomalies.

Neurenteric cysts are considered to be a form of OSD, as are the following entities: lipoma, lipomyelomeningocele, SCMs, meningocele manqué, dermal sinus tract inclusion cysts (dermoids and epidermoids), terminal syringohydromyelia, and myelocystocele. A consistent association between neurenteric cysts and these other forms of OSD has not been reported. In analyzing our 13 cases, we were struck by both their fascinating case histories as well as the incredible diversity of associated findings (typically either other forms of OSD or the various cutaneous and orthopedic stigmata of OSD). We present these patients in detail, compare them with other large reported series, and discuss possible causes of intraspinal neurenteric cysts.

\section{CASE MATERIAL AND METHODS}

The patients in this series were treated over a 50-year period in large part by the senior author (W.J.O.). Patients for whom either operative data or histological results were incomplete were excluded from this study. Complete records for 13 patients formed the basis for this study. 
TABLE 1

Characteristics of 13 patients with spinal neurenteric cysts*

\begin{tabular}{|c|c|c|c|c|c|c|c|c|}
\hline $\begin{array}{l}\text { Case } \\
\text { No. }\end{array}$ & $\begin{array}{l}\text { Age } \\
(y r s) \\
\text { Sex }\end{array}$ & Presentation & $\begin{array}{c}\text { Cyst } \\
\text { Location }\end{array}$ & $\begin{array}{l}\text { Relation } \\
\text { of Cyst to } \\
\text { Spinal Cord }\end{array}$ & Level & $\begin{array}{l}\text { Bone Ab- } \\
\text { normalities }\end{array}$ & $\begin{array}{l}\text { Cutaneous } \\
\text { Stigmata }\end{array}$ & $\begin{array}{l}\text { Other Forms } \\
\text { of OSD }\end{array}$ \\
\hline 1 & $\begin{array}{c}52 \text { yrs, } \\
\text { F }\end{array}$ & $\begin{array}{l}\text { neck pain, rt arm } \\
\text { numbness \& } \\
\text { weakness }\end{array}$ & $\begin{array}{l}\text { intradural, ex- } \\
\text { tramedullary }\end{array}$ & anterior & $\mathrm{C} 2-\mathrm{C} 3$ & Klippel-Feil & none & none \\
\hline 2 & $\begin{array}{c}17 \text { yrs, } \\
\text { M }\end{array}$ & $\begin{array}{l}\text { pain, leg length } \\
\text { discrepancy }\end{array}$ & $\begin{array}{l}\text { intradural ex- } \\
\text { tramedullary }\end{array}$ & dorsal & $\mathrm{T} 12-\mathrm{L} 2$ & $\begin{array}{l}\text { scoliosis, spina } \\
\text { bifida, T-11 } \\
\text { hemivertebrae }\end{array}$ & hairy patch & $\begin{array}{l}\text { SCM, tethered } \\
\text { cord }\end{array}$ \\
\hline 3 & $\begin{array}{l}9 \text { yrs, } \\
\text { F }\end{array}$ & $\begin{array}{l}\text { back pain, lt pain } \\
\& \text { numbness }\end{array}$ & $\begin{array}{l}\text { intradural, ex- } \\
\text { tramedullary }\end{array}$ & anterolat & $\mathrm{C} 2-3$ & $\begin{array}{l}\text { hole in C-3 VB, } \\
\text { scoliosis }\end{array}$ & none & none \\
\hline 4 & $\begin{array}{c}23 \mathrm{yrs}, \\
\mathrm{M}\end{array}$ & $\begin{array}{l}\text { back pain, progres- } \\
\text { sive leg weakness }\end{array}$ & $\begin{array}{l}\text { intradural, ex- } \\
\text { tramedullary }\end{array}$ & dorsal & $\mathrm{T} 1-2$ & spina bifida & $\begin{array}{l}\text { peduncu- } \\
\text { lated mass }\end{array}$ & $\begin{array}{l}\text { dorsal meningo- } \\
\text { cele }\end{array}$ \\
\hline 5 & $\begin{array}{c}10 \mathrm{wks}, \\
\mathrm{M}\end{array}$ & $\begin{array}{l}\text { LUQ mass, post- } \\
\text { mediastinal mass }\end{array}$ & $\begin{array}{l}\text { intradural, ex- } \\
\text { tramedullary }\end{array}$ & anterior & $\mathrm{T} 2-3$ & $\begin{array}{l}\text { thoracic hemi- } \\
\& \text { butterfly ver- } \\
\text { tebrae, scoliosis }\end{array}$ & none & none \\
\hline 6 & $\begin{array}{c}4 \text { yrs, } \\
\text { M }\end{array}$ & back pain & $\begin{array}{l}\text { intradural, ex- } \\
\text { tramedullary }\end{array}$ & dorsal & L1-3 & spina bifida & $\begin{array}{l}\text { cutaneous } \\
\text { hemangi- } \\
\text { oma }\end{array}$ & none \\
\hline 7 & $\begin{array}{c}5 \text { wks, } \\
\text { F }\end{array}$ & lumbar mass & $\begin{array}{l}\text { extradural (sub- } \\
\text { cutaneous) }\end{array}$ & $\begin{array}{r}\text { dorsal (sub- } \\
\text { cutaneous) }\end{array}$ & L1-2 & $\begin{array}{l}\text { multiple spina } \\
\text { bifida (L1-S1) }\end{array}$ & $\begin{array}{l}\text { hairy patch, } \\
\text { sacral mass } \\
\text { \& dimple }\end{array}$ & $\begin{array}{l}\text { adjacent intradu- } \\
\text { ral lipoma, non- } \\
\text { adjacent subcu- } \\
\text { taneous lipoma }\end{array}$ \\
\hline 8 & $\begin{array}{c}8 \text { yrs, } \\
\mathrm{M}\end{array}$ & back \& rt leg pain & $\begin{array}{l}\text { intradural, in- } \\
\text { tramedullary }\end{array}$ & $\begin{array}{l}\text { intramed- } \\
\text { ullary }\end{array}$ & L-5 & spina bifida & $\begin{array}{l}\text { dermal sinus } \\
\text { tract, hairy } \\
\text { patch, capil- } \\
\text { lary heman- } \\
\text { gioma }\end{array}$ & $\begin{array}{l}\text { tethered cord w/ } \\
\text { thickened filum, } \\
\text { lipoma }\end{array}$ \\
\hline 9 & $\begin{array}{l}1 \mathrm{yr}, \\
\mathrm{F}\end{array}$ & $\begin{array}{l}\text { lumbar subcutaneous } \\
\text { mass }\end{array}$ & subcutaneous & $\begin{array}{l}\text { dorsal (sub- } \\
\text { cutaneous) }\end{array}$ & T11-L2 & spina bifida & $\begin{array}{l}\text { subcutaneous } \\
\text { mass }\end{array}$ & intradural lipoma \\
\hline 10 & $\begin{array}{c}51 \mathrm{yrs}, \\
\mathrm{M}\end{array}$ & $\begin{array}{c}\text { progressive pain \& } \\
\text { numbness in legs }\end{array}$ & $\begin{array}{l}\text { intradural, in- } \\
\text { tramedullary }\end{array}$ & $\begin{array}{l}\text { intramed- } \\
\text { ullary }\end{array}$ & $\mathrm{T} 2-3$ & spina bifida & $\begin{array}{l}\text { subcutaneous } \\
\text { mass }\end{array}$ & $\begin{array}{l}\text { syringomyelia, } \\
\text { dorsal tethering }\end{array}$ \\
\hline 11 & $\begin{array}{c}45 \text { yrs, } \\
\text { F }\end{array}$ & $\begin{array}{l}\text { progressive parapa- } \\
\text { resis }\end{array}$ & $\begin{array}{l}\text { intradural, ex- } \\
\text { tramedullary }\end{array}$ & dorsal & $\mathrm{T} 4-7$ & spina bifida & hairy patch & $\begin{array}{l}\text { SCM, intramedul- } \\
\text { lary lipoma, } \\
\text { tethered cord } \\
\text { from thickened } \\
\text { filum, meningo- } \\
\text { cele manqué }\end{array}$ \\
\hline 12 & $\begin{array}{c}19 \text { yrs, } \\
\text { F }\end{array}$ & mirror movements & $\begin{array}{l}\text { intradural, in- } \\
\text { tramedullary }\end{array}$ & $\begin{array}{l}\text { intramed- } \\
\text { ullary }\end{array}$ & T12-L2 & Klippel-Feil & none & $\begin{array}{l}\text { SCM, intradural } \\
\text { lipoma }\end{array}$ \\
\hline 13 & $\begin{array}{l}6 \text { wks, } \\
\text { F }\end{array}$ & hairy patch & $\begin{array}{l}\text { intradural, in- } \\
\text { tramedullary }\end{array}$ & $\begin{array}{l}\text { intramed- } \\
\text { ullary }\end{array}$ & T12-L2 & none & hairy patch & SCM \\
\hline
\end{tabular}

* LUQ = left upper quadrant.

\section{RESULTS}

\section{Patient Demographics}

The patients ranged in age from 5 weeks to 52 years. Patients most commonly presented either early in life (first two decades) or well into adulthood (fourth or fifth decades). The youngest patients typically presented with cutaneous stigmata indicative of OSD whereas the older patients presented with pain or neurological dysfunction. There was a slight female preponderance (1.2:1) which is in contrast to previous reports in which a male preponderance has been reported ${ }^{2,4,54}$ (Table 1).

\section{Cyst Location}

The cysts in this series were found in a variety of locations, all of which were consistent with the proposed classification of developmental posterior enteric remnants proposed by Bentley and $\mathrm{Smith}^{6}$ (Fig. 1). In relation to the spinal cord, the most common location was dorsal to the cord (either as an intradural extramedullary mass [four cases] or as an extradural dorsal mass [two cases]). The second most common location was intramedullary (four cases), followed by an anterior or anterolateral position (three cases). The cysts appeared in all regions of the spine, ranging from C-2 to L-5 (Table 1). We found no cysts at the craniocervical junction or in an intracranial location. The most common location was at the thoracolumbar junction (six cases), followed by the upper-thoracic region (four cases), cervical region (two cases), and, least commonly, the lower-lumbar spine (one case). In our series the location and position of the neurenteric cysts differed from the preferred location (that is, in the cervical spine with an anterior relationship to the cord) that has been previously reported by many authors. ${ }^{15,30,31,38,54}$

\section{Neuroimaging Findings}

Many of the patients presented prior to the advent of MR imaging. Computerized tomography myelography 


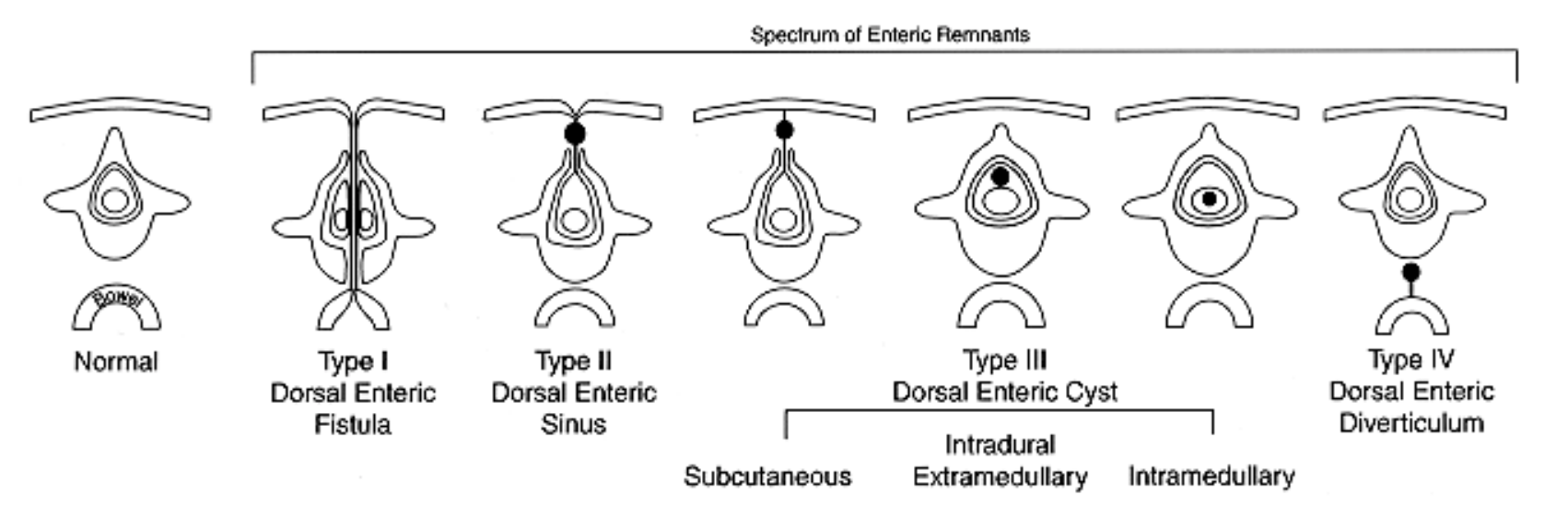

Fig. 1. Developmental posterior enteric remnants. Classification by Bentley and Smith.

demonstrated the lesions typically as a complete or partial block at the appropriate levels, but often the diagnosis of neurenteric cyst was an unexpected finding at surgery. Other bone abnormalities such as diastematomyelia were well demonstrated on these imaging studies. In our later patients, MR imaging revealed the neurenteric cysts to be typically isointense to hyperintense relative to cerebrospinal fluid on long-relaxation time sequences. On $\mathrm{T}_{1}$ weighted MR imaging they appeared isointense or slightly hyperintense to cerebrospinal fluid. Based on reports in the literature, these signal characteristics are typicaly and correlate with the high-protein content fluid within the cysts. ${ }^{9,19}$ Using MR imaging, were able to make a presumptive diagnosis of neurenteric cyst in most of these patients preoperatively.

\section{Histopathological Examination}

Neurenteric cysts are classified by the World Health Organization under the heading of "other malformative tumors and tumor-like lesions" and are described as cysts "lined by mucin secreting epithelium resembling that of the gastrointestinal tract." ${ }^{55}$ Wilkins and Odum ${ }^{53}$ have classified these cysts into three types based on the histological features of the cyst wall and its contents. The walls of Type A cysts mimic gastrointestinal or respiratory epithelium with a basement membrane supporting single or pseudostratified cuboidal or columnar cells, which may be ciliated. Type B cysts also contain glandular organization, usually producing mucin or serous fluid. Type C cysts are the most complex containing ependymal or glial tissue within the cyst. In our series, one patient $(8 \%)$ harbored a simple Type A cyst, 10 patients $(77 \%)$ harbored the moderately complex Type B cyst, and two patients (15\%) harbored the most complex Type $\mathrm{C}$ cyst (Table 2). It has been reported that neurenteric cysts with associated abnormalities are of greater histological complexity as compared with those cysts without associated dysraphic features. Our findings support this association. Paleologos, et al., ${ }^{42}$ compared the pathological features of 136 reported cases of neurenteric cysts and divided them into two groups: 80 patients with neurenteric cysts without associated dysraphism and 56 patients harboring neurenteric cysts with associated dysraphism. In the nondysraphic group $84 \%$ of

TABLE 2

Histopathological findings in 13 patients with neurenteric cysts*

\begin{tabular}{|c|c|c|}
\hline $\begin{array}{c}\text { Case } \\
\text { No. }\end{array}$ & Histopathological Finding & $\begin{array}{c}\text { Wilkins } \\
\text { \& Odum } \\
\text { Classification }\end{array}$ \\
\hline 1 & single-layer columnar epithelial cells w/ basement membrane \& microvilli & A \\
\hline 2 & single-layer columnar cells w/ mucin droplets; smooth-muscle cells \& glial tissue & $\mathrm{C}$ \\
\hline 3 & columnar epithelium w/ mucin glands (PAS positive) & $\mathrm{B}$ \\
\hline 4 & columnar epithelium w/ mucin glands & $\mathrm{B}$ \\
\hline 5 & columnar \& squamous epithelium w/ mucous glands & B \\
\hline 6 & ciliated columnar to flattened epithelium w/ mucin droplets \& mucin glands & $\mathrm{B}$ \\
\hline 7 & columnar epithelium w/ mucin glands similar to respiratory glands & $\mathrm{B}$ \\
\hline 8 & columnar epithelium w/ smooth-muscle cells, cartilage (PAS positive) & $\mathrm{B}$ \\
\hline 9 & single-layer columnar epithelial cells w/ basement membrane; PAS-positive glands resembling GI tissue & $\mathrm{B}$ \\
\hline 10 & cuboidal epithelium w/ mucin glands \& goblet cells & $\mathrm{B}$ \\
\hline 11 & columnar epithelium w/ mucin glands resembling GI tissue & $\mathrm{B}$ \\
\hline 12 & columnar epithelium w/ mucin glands & $\mathrm{B}$ \\
\hline 13 & $\begin{array}{l}\text { single-layer columnar epithelial cells resembling GI \& respiratory-like mucosa; mucin glands, smooth-muscle } \\
\text { cells, cartilage, \& glial tissue also noted }\end{array}$ & $\mathrm{C}$ \\
\hline
\end{tabular}

${ }^{*} \mathrm{GI}=$ gastrointestinal; PAS $=$ periodic-acid Schiff. 
M. J. Rauzzino, et al.

TABLE 3

Outcome in 13 patients after surgical treatment

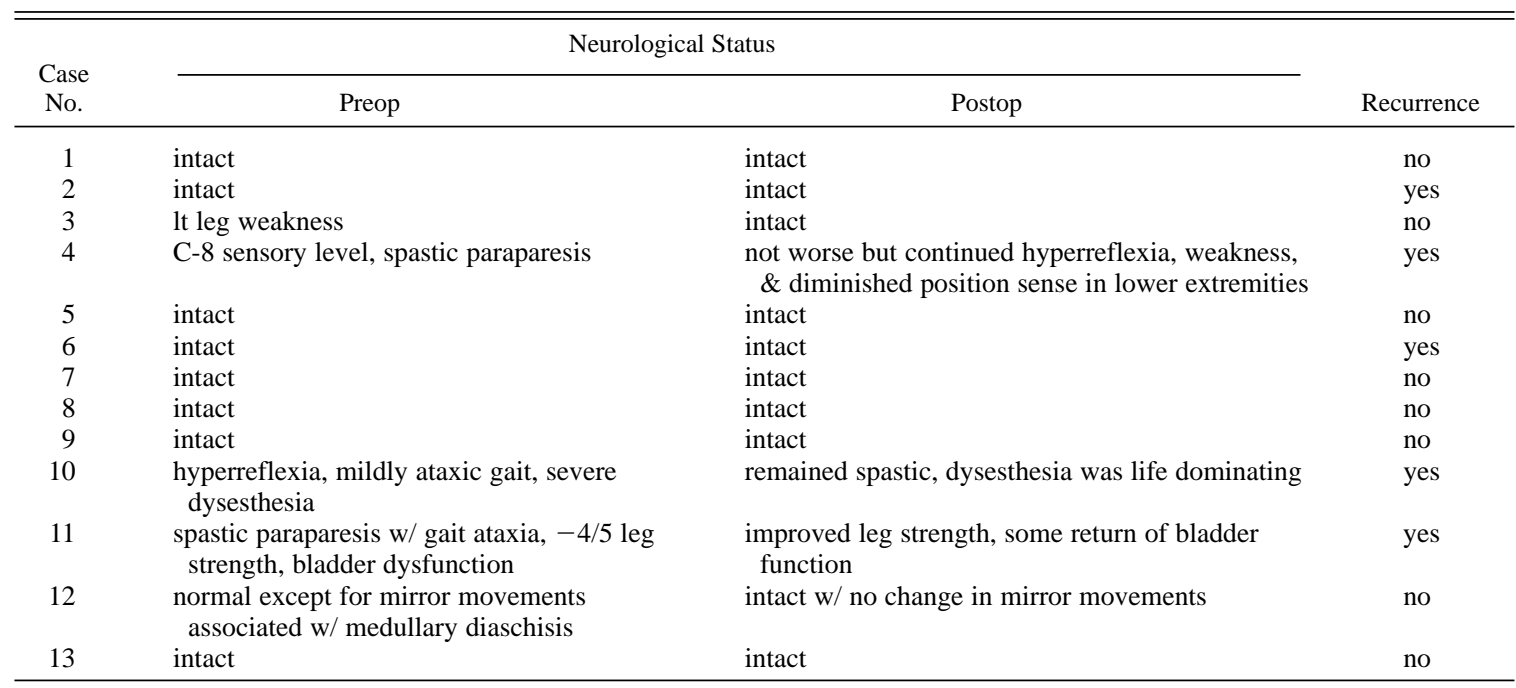

patients harbored the simplest Type A cyst, and in the dysraphic group only $39 \%$ had a similar lesion type.

\section{Patient Outcome}

The relatively benign nature of these slow-growing lesions is evident by the good outcome experienced by most patients in this series (Table 3). Postoperative neurological status typically reflected the preoperative status, and no patients experienced worsened symptoms after undergoing surgery. There was a cyst recurrence rate of $27 \%$ in our series after the cyst had been incompletely resected (either by us or by a previous surgeon). These recurrences occurred early in our series because, in the later part of the series, a significant attempt was made to resect the entire cyst wall if the intraoperative diagnosis of neurenteric cyst was considered and if this was technically possible without causing significant neurological deficit.

\section{Associated Abnormalities}

Vertebral Abnormalities. All but one of these patients $(92 \%)$ presented with some form of vertebral abnormality, often at multiple levels. Anterior vertebral column abnormalities were seen in five patients (39\%) including two patients (15\%) with Klippel-Feil abnormalities. Posterior vertebral column abnormalities were found in eight patients $(62 \%)$, most typically as some form of spina bifida. Scoliosis-related spinal deformity was present in two patients $(15 \%)$ with the scoliosis resulting from thoracic hemivertebrae.

Cutaneous Stigmata. A number of cutaneous stigmata have been associated with OSD, but rarely has this association been made with neurenteric cysts. Nine $(69 \%)$ of our 13 patients had some form of cutaneous stigmata, and some had multiple stigmata. The cutaneous stigmata included focal hirsutism (five cases), subcutaneous mass (three cases), flat capillary hemangioma (two cases), dermal sinus tract (two cases), and pedunculated mass (one case). In the three youngest patients in this series, it was the presence of this cutaneous stigmata that led to the early diagnosis of the neurenteric cyst.

\section{Associated Forms of Spinal Dysraphism}

Nine patients (69\%) harbored a neurenteric cyst accompanied by another form of spinal dysraphism in which three were intraspinal abnormalities. Four patients (31\%) harbored a cyst in which there were no other intraspinal abnormalities. The most common associated findings were SCM (31\%) or associated intradural lipoma (31\%). A tethered spinal cord caused by a thickened terminal filum was found in three patients (23\%). There was also one case each of a dorsal meningocele, syringomyelia, and meningocele manqué ( $8 \%$, respectively).

\section{ILLUSTRATIVE CASES}

\section{Case 1}

This 52-year-old woman presented with a 4-year history of neck and right arm pain, which progressed over several months to include numbness and weakness. Cervical myelography demonstrated an anterior intradural extramedullary mass at the $\mathrm{C} 2-3$ level. Plain radiography revealed a congenital fusion of the C-2 and C-3 VBs. A cervical laminectomy was performed, and at surgery, the spinal cord was shown to be displaced posteriorly by a cystic mass from which clear fluid was aspirated. The wall of the cyst consisted primarily of a single layer of columnar epithelium with some ciliation resting on a thick basement membrane. Postoperatively, electron microscopy showed signs of mucinous granuoles, microvilli, and nuceli consistent with an intestinal origin. The patient awoke without deficit and had relief of her neck and arm pain.

\section{Case 2}

This 17-year-old man presented with a 2-year history of worsening low-back pain. He was noted to have scoliosis 


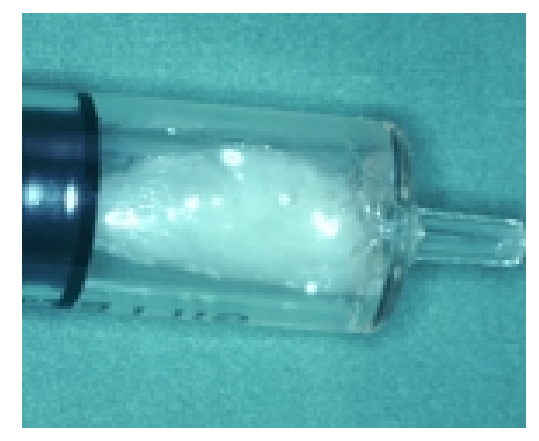

Fig. 2. Case 2. Mucous material aspirated from cyst. Path pneumonia for a neurenteric cyst.

and a leg-length discrepancy for which he wore an orthotic device. Physical examination revealed a hairy patch in the upper-lumbar area and increased reflexes in his lower extremities. He had a $20^{\circ}$ levoconvex thoracolumbar curve with a hemivertebra at T-11. Computerized tomography myelography demonstrated an SCM with a bone spur and the conus medullaris tethered by an abnormally thick terminal filum. An intradural extramedullary lesion was noted just above the splitting of the cord. The patient underwent a laminectomy without fusion, and at surgery an intradural cystic lesion was found at T-11, which was filled with a thick mucinous material (Fig. 2). The bone spur was drilled down, releasing the hemicords, and the filum was sectioned. Histopathological examination of the cyst wall showed a single layer of columnar cells with mucin droplets. Some smooth-muscle cells and glial tissue were noted. The patient awoke without deficit. At the 15year follow up, he was noted to be doing well without significant progression of his scoliosis.

\section{Case 3}

This 9-year-old child with a progressive congenital cervicothoracic scoliosis presented with a 1-year history of neck pain that progressed to torticollis. Left leg pain and weakness developed and a cervical myelogram revealed an anterior intradural extramedullary mass. A cervical laminectomy was performed, and at surgery the spinal cord was shown to be displaced posteriorly by a cystic mass, which was intradural and anterolateral to the cord on the right. The cyst was opened, and a thick mucous component was noted. A circular opening in the anterior dura was observed just to the right of the midline at $\mathrm{C}-3$ with tissue continuing into the VB. The tissue was ligated. Histopathological examination showed columnar epithelium with mucin glands. Postoperatively the patient experienced resolution of left leg weakness. At the 5-year follow-up review, the patient was asymptomatic.

\section{Case 4}

This 23-year-old man presented with spina bifida of the upper-thoracic spine. At age 15 years he had developed neck and shoulder pain, which was aggravated by coughing. Physical examination showed a small pedunculated mass in the midline at $\mathrm{T}-2$. He was then believed to have a small dorsal bony spina bifida with a meningocele and the cord fixated dorsally. Two years later he developed left arm pain and ataxic gait with bilateral leg weakness. He declined surgery at the time. He presented at age 30 years with a progressive upper-thoracic scoliosis, increased leg weakness, and urinary hesitancy. He underwent a T1-2 laminectomy in which a large intradural dermoid cyst was removed and a dorsal meningocele was excised and repaired. The stalk of the meningocele contained clear fluid that passed through a bifid T-1 lamina. A dorsally located, encapsulated mass containing grayish gelatinoid material extended from C-6 to T-2 and was partially excised. The patient presented 10 years later with a 3-day history of progressive paraparesis and a C-8 sensory level. A myelogram demonstrated a complete block at T-2, and he underwent a C7-T3 laminectomy. A thin-walled extramedullary cyst containing mucus was totally excised. The cyst wall was lined by columnar epithelium with underlying mucous glands. The patient experienced improvement of his lower-extremity strength, but a spastic gait, hyperreflexia, and diminished position sense in his legs remained.

\section{Case 5}

This 10-week-old boy was noted to have a left upperquadrant mass that enlarged in the first few weeks of life. His neurological status was normal, and CT scanning demonstrated a smooth cystic mass in the left upper quadrant and a smaller paravertebral mass in the posterior mediastinum. Plain radiographs of the chest demonstrated multiple thoracic hemi- and butterfly vertebrae. Exploratory laparotomy revealed an enteric duplication cyst. The posterior mediastinal cyst was removed by thoracotomy, and a connection was seen attached to the T- 4 VB. A thoracic laminectomy was performed, and an intradural extramedullary cyst that displaced the cord dorsally and laterally, was removed. The cyst wall was noted to have columnar and squamous epithelium with mucinous glands. The patient remained neurologically intact.

\section{Case 6}

This 4-year-old boy presented with a 1-year history of back pain. Neurological examination demonstrated normal findings, but the patient was noted to have a capillary hemangioma over the lumbar spine. Plain radiography demonstrated a bifid L-5 vertebra and an expanded lumbar canal. Computerized tomography myelography revealed an intradural extramedullary tumor at L-1 and a mass posterior to the cord. A T12-L4 laminectomy was performed, and a midline intradural cystic tumor was found that seemed to arise from the cord and blend with it laterally. Histologically, the cyst consisted of ciliated columnar to flattened epithelium with mucin droplets as well as mucous glands. The patient underwent a repeated subtotal resection 1 year later and eventually at age 10 years required a third operation in which complete excision of the cyst was achieved. He has remained neurologically intact and free from recurrence at 30 years of age.

\section{Case 7}

This 5 1/2-week-old girl was noted at birth to have a sacral mass and dimple with a hairy patch (Fig. 3 left). Plain radiography demonstrated multiple posterior arch defects, and CT myelography demonstrated two areas of malfor- 


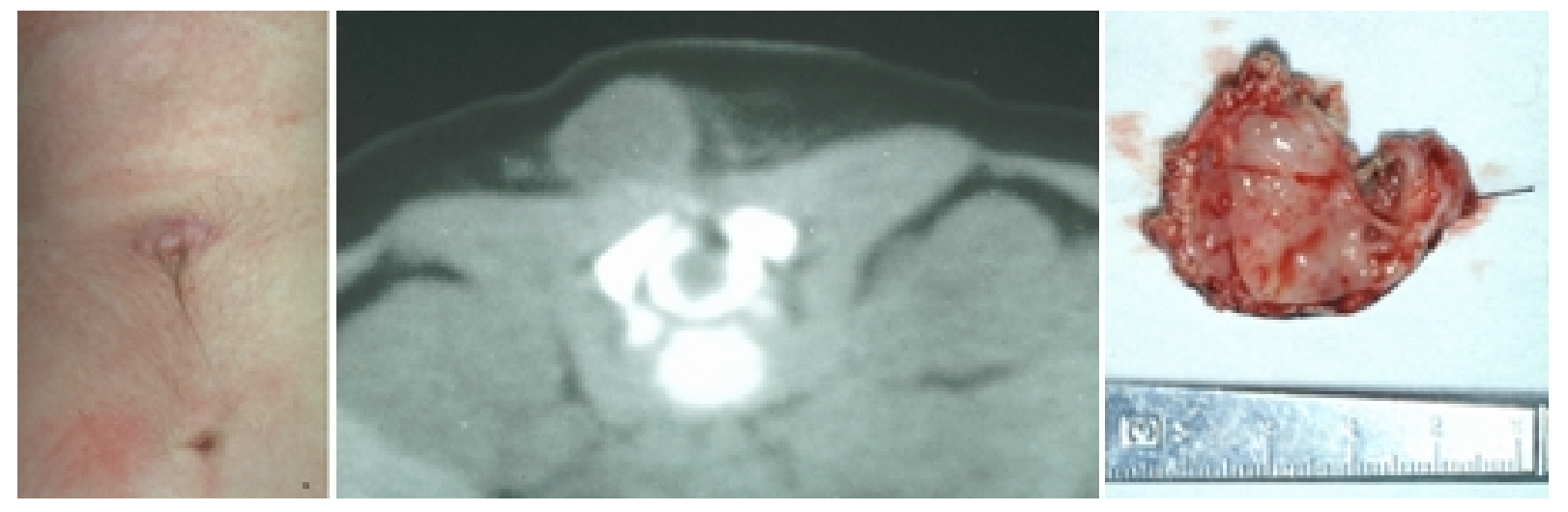

Fig. 3. Case 7. Left: Back of a patient with an atretic meningocele surrounded by excessive hair. Below this is a dermal sinus. Center: Axial CT myelogram demonstrating a subcutaneous mass (neurenteric cyst) and small lipoma dorsal to the spinal cord. Right: Subcutaneous cyst opened to visualize the complex inner lining of the lesion.

mation (Fig. 3 center). The first was at the L1-3 level where, in the subcutaneous tissue, a water-density cyst was observed that had a stalk extending through the lumbodorsal fascia. Additionally, at the lumbodorsal fascia two posterior fat density masses were noted to compress the cord. The second area was at L5-S1 where the neural arches were disrupted and bone compression of the thecal sac had developed. An extradural fatty tumor was also noted at this level. At surgery a subcutaneous bluish cystic structure, yielding milky mucinous fluid, narrowed to a thickened fibrous structure that pierced the dura and attached dorsally to the cord at L1-2. An intradural exploration revealed two lipomatous masses lying on either side of the cord. The dermal pit and hair tuft at L5-S1 was found to overlie a subcutaneous lipoma that entered the dura at the L-5 level. Histological examination of the subcutaneous cyst showed columnar epithelium with glandular structures containing apical mucin similar to respiratory tract epithelium (Fig. 3 right). At the 7-year follow-up examination the patient remained neurologically intact and experienced no recurrence of lesions.

\section{Case 8}

This 8-year-old boy presented with a 2-year history of neck, back, and right leg pain. At birth he had been noted to have a dermal sinus tract in the lumbar region surrounded by a capillary hemangioma and a hair tuft. On plain x-ray films obtained at that time, an L-5 spina bifida was observed, and focal swelling of the conus medullaris was demonstrated on air myelography. He underwent surgical sectioning of the filum and was then lost to follow up. He presented at 8 years of age with recurrent back pain and incontinence precipitated by coughing. Repeated CT myelography demonstrated focal swelling in the conus medullaris extending over three vertebral segments. An L1-4 laminectomy was performed, and on opening the dura, the dorsal surface of the conus medullaris was replaced by a cystic swelling (Fig. 4). During removal of the cyst, thick mucinous fluid was spilled. Histological examination of the cyst wall showed a columnar epithelium and evidence of smooth-muscle cells and cartilage. The tissue sample stained periodic-acid Schiff positive, and the lesion was diagnosed as a neurenteric cyst. At the 12-year follow-up examination, the patient was asymptomatic except for occasional pains shooting down the right leg.

\section{Case 9}

This 1-year-old girl had undergone an attempted excision of a subcutaneous lumbar mass; however, the general surgeon had aborted the procedure when the cyst was discovered to have a stalk that pierced the lumbodorsal fascia. The tract was tagged and the wound closed. Subsequent MR imaging revealing a thoracic spina bifida and what was believed to be an intradural, extramedullary mass in association with the extradural neurenteric cyst. At the second surgery, the remainder of the subcutaneous cyst was seen to pass through the L-1 spina bifida where a sizable portion of the cyst extradurally compressed the thecal sac. On opening the dura, a sizable lipomatous mass was observed to be adherent to the dorsal surface of the spinal cord. Histopathological examination of the cyst wall showed single-layer columnar epithelial cells with a basement membrane and periodic-acid Schiff-positive glands resembling gastrointestinal tissue. The patient awoke neurologically intact.

\section{Case 10}

This 51-year-old man presented with a 3-month history of neck pain, and a burning sensation and numbness in his lower extremities. He had an interesting history. As an infant spina bifida had been diagnosed, and a mass was ex-

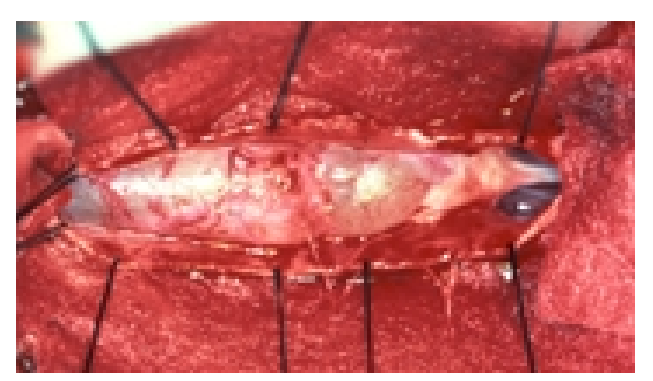

Fig. 4. Case 8. Intraoperative photograph of a dorsally located cyst at the level of the conus medullaris. 


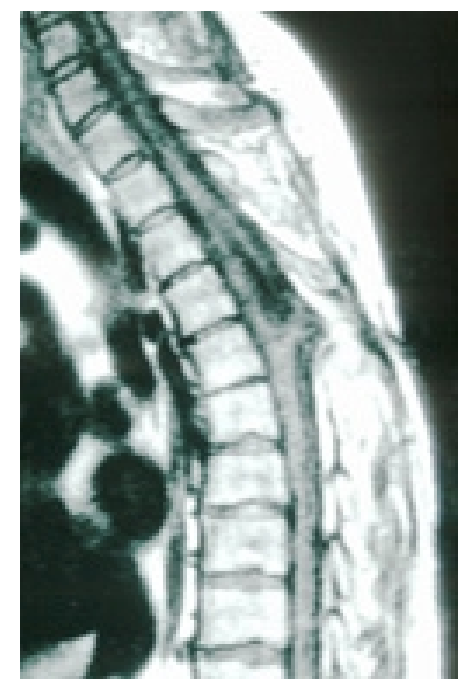

Fig. 5. Case 10. Midsagittal $\mathrm{T}_{2}$-weighted MR image of intramedullary cyst with a dermal sinus tract.

cised from his interscapular region. At presentation his neurological status was normal except for subtle long tract signs and mildly ataxic gait. Preoperative MR imaging revealed a previous thoracic laminectomy with a dermal sinus tract leading to an intramedullary cystic mass and dorsal adhesion of the cord (Fig. 5). Additionally a noncontiguous syrinx was observed in the upper-cervical region. At surgery, the dura was reopened, and in the midline, a large intramedullary cystic mass within the central portion of the cord was easily visualized. Mucous was aspirated from the cyst and an attempt was made to excise the cyst wall. The spinal cord was untethered from the dorsal adhesions, and the syrinx above was shunted into the subarachnoid space. Histopathological examination of the cyst wall showed cuboidal epithelium with mucin glands and goblet-shaped cells. The patient awoke without additional deficit and experienced relief of his pain. His bilateral lower-extremity spasticity persisted. Within 2 months his dysesthetic pain had returned.

\section{Case 11}

This 45-year-old woman presented with increasing paraparesis. She had undergone a spine operation as a 6 -week-old infant, but the operative report and pathological results were not available for review. She did not present again until age 37 years when she developed an acute paraparesis after a minor traumatic injury. She underwent a second operation for removal of what was described as an intramedullary teratoma. She recovered but over the next 9 years developed increasingly severe back pain, lower-extremity weakness, and bladder dysfunction. Preoperative MR imaging demonstrated two areas of SCM (one bone septum and one fibrous septum), an intramedullary cyst, an intramedullary mass consistent with lipoma, and a tethered cord from a thickened terminal filum. At surgery the neurenteric cyst was noted to arise dorsal to the two hemicords, and it contained characteristic mucous material. A number of dorsal tethering bands (meningocele manqué) were found and sectioned in addition to the filum. The intramedullary lipoma above the cyst was partially debulked. Histopathological examination showed columnar epithelium with mucin glands that resembled gastrointestinal tissue. The patient awoke without new deficit. Her leg weakness and bladder dysfunction were improved but not normalized.

\section{Case 12}

This 19-year-old woman presented with neck pain that was found to be associated with an extensive fusion process of her cervical spine. At presentation, she was noted to have extensive mirror movements as part of her Klippel-Feil syndrome. A brain and cervical spine MR imaging study demonstrated medullary diaschisis and the aforementioned bone changes but no cervical spinal cord disease. As part of her workup, a total spine MR imaging study was ordered, and unexpectedly, an incidental finding was made of a major abnormality of the conus medullaris. This included an SCM with a cystic mass distorting the left hemicord, fatty tissue between the two hemicords, and tethering of the cord at this level (Fig. 6). After a long discussion with the family, it was thought that the natural history of this lesion could represent leg weakness, and the family desired the patient undergo excision of the mass. At surgery via a posterior laminectomy, the cystic mass in the left hemicord yielded thick mucinous fluid. The intramedullary cyst wall was only partially excised. There was a calcified spur separating the two hemicords and a dorsally located intradural lipoma, which was resected. Histopathological examination of the cyst wall showed a single layer of columnar epithelium with a large number of mucin glands. The patient awoke without deficit and remains well now 6 years postoperatively. The cyst has gradually refilled as documented by MR imaging.

\section{Case 13}

This 6-week-old girl presented with a hairy patch over the thoracolumbar junction. Her family history was remarkable for having a sibling and a cousin born with a myelomeningocele. An MR imaging study demonstrated an intradural dumbbell-shaped mass that appeared to arise from the dorsum of the cord. A posterior laminectomy was performed, and the dura was opened in the midline to reveal a cystic lesion. The cyst was aspirated, yielding

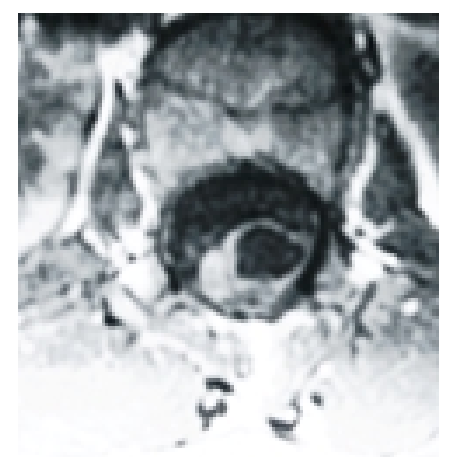

Fig. 6. Case 12. Axial $\mathrm{T}_{2}$-weighted MR image of neurenteric cyst arising from a hemicord. 
M. J. Rauzzino, et al.

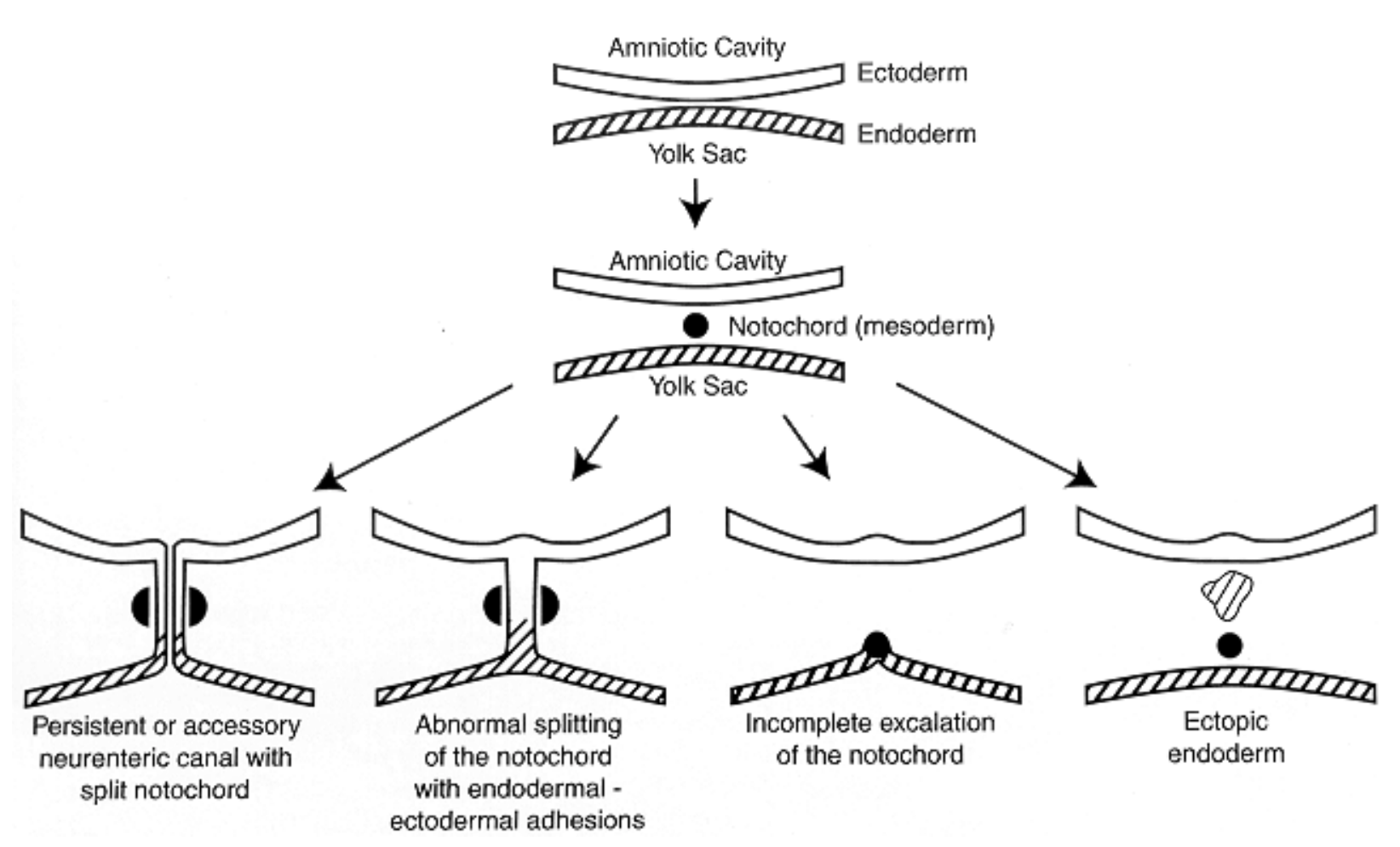

Fig. 7. Proposed embryologic mechanisms for neurenteric cyst formation. Modified from MacDonald, et al.

mucinous material, and unexpectedly, it became obvious that there were two distinct hemicords between which the tumor arose. Histopathological examination showed a complex cystic lesion in which there were single-layer columnar epithelial cells with a basement membrane. Both gastrointestinal- and respiratory-like mucosa were noted with mucin glands and some smooth-muscle cells and cartilage. The patient awoke without deficit and is healthy now at 7 years of age.

\section{DISCUSSION}

\section{Embryological Development}

A number of theories have been proposed to explain the occurrence of endodermal tissue in the central nervous system. 5,6,8,13,25,33,39,45 A knowledge of early embryological development is necessary to understand these theories. Any theory would have to allow not only for the formation of the cyst but also account for the myriad abnormalities that often accompany the cyst. As bone defects are commonly associated with these cysts, it would seem likely that the primary event would occur within the first 3 weeks of gestation during gastrulation when these endodermal and mesenchymal layers are intimately associated with each other. Initially, the fertilized embryo consists of a bilaminar disc containing layers of endoderm and ectoderm. A groove, termed the primitive streak, then forms on the caudal portion of the ectodermal surface and terminates as an elevation known as the Hensen node. Mesodermal cells migrate through the primitive streak and continue in lateral and cephalic directions to form the notochord of the trilaminar germ disc by the end of the 3 week of gestation. There is a connection called the neurenteric canal that is usually transient and connects the amniotic cavity and the yolk sac through the primitive pit. A tube of mesoderm condenses to form the notochord and paraxial mesoderm cells migrate around the notochord as precursors to the future vertebral column. The notochord also induces the overlying ectoderm to form the neural plate, which will eventually fold on itself, and close during the 4th gestational week to form the neural tube.

The main theories for neurenteric cyst formation include: 1) a primary adhesion of endoderm anterior to the notochord, 2) incomplete excalation of the notochord, 3) persistence of the neurenteric canal or formation of an accessory neurenteric canal with a split notochord, and 4) displacement of endodermal cells (Fig. 7).

Beardmore and Wigglesworth ${ }^{5}$ proposed that during the outgrowth of the notochord an adhesion could form between the endoderm and ectoderm that would become a barrier to the elongating notochord and thereby splitting it. The paired neuroepithelial precursors could then develop independently, forming two hemicords, and the endodermal remnants of the adhesion could then be found anywhere between the gut and the surface ectoderm.

Rhaney and Barclay ${ }^{47}$ suggested that aberrant intercalation or excalation of the notochord could lead to strands of endodermal remnants that could traverse a secondarily split notochord.

Bremer ${ }^{8}$ postulated that neurenteric cysts and diastematomyelia could be explained by the persistence of a neurenteric canal. He noted that because most neurenteric cysts are located more rostrally in the spine and the neurenteric canal is ultimately destined for the caudal end of the spine, an accessory canal is more likely to be the cau- 
sative factor than persistence of the original neurenteric canal. As part of a unified theory of SCMs, Pang, et al., ${ }^{44}$ have proposed that a secondary neurenteric tract may develop and become invested with mesenchymal tissue that splits the notochord and neural plate. Depending on the timing of such an event, two hemicords might develop with a cleft between them that could go on to form a bone spur with the potential to tether the cord. This theory would explain the association of SCMs with neurenteric cysts demonstrated in our series.

Bentley and Smith ${ }^{6}$ expanded Bremer's theory, postulating that the splitting of the notochord is the primary event. The subsequent deficiency in the overlying neural plate could allow for an endodermal diverticulum to herniate through the spinal column and make contact with the surface ectoderm. In such a situation the persistence of the neurenteric connection which occurs may be transient or permanent, partial or complete (Fig. 1).

A number of scenarios may potentially result from this scheme. 1) If only the ventral portion remains, then a duplication of the alimentary canal without associated spinal abnormalities can occur. 2) If, on the other hand, only the terminal dorsal portion persists, then a cutaneous abnormality possibly associated with a sinus might result. 3) If the midportion only persists and if the cleft in the VB is incompletely obliterated, then anterior spina bifida and possibly diastematomyelia may result. If the cleft in the $\mathrm{VB}$ is transient and incomplete, then an intraspinal cyst can occur in the absence of permanent anterior bone anomalies. 4) Any combination of the aforementioned three scenarios may occur. This split notochord theory is attractive because it provides an easily understandable mechanism that can account for the entire spectrum of lesions in our series, including the presence of dorsally located lesions. However, this theory does not explain the formation of neurenteric cysts in their entirety. There have been well-documented cases of neurenteric cysts in an intracranial location, and these lesions would not be predicted by this theory. It is possible, then, that neurenteric cysts may occur by all or none of the previously mentioned theories

\section{Comparison With Previous Reports}

A neurenteric cyst is classically reported as a solitary lesion in the cervical region, located anterior or anterolateral to the cord. ${ }^{21,54}$ Bone abnormalities, if present, are likely to involve the anterior column. Wilkins and Odum ${ }^{53}$ initially reviewed 47 patients with reported neurenteric cysts and later Wilkins and Rossitch ${ }^{54}$ added another 66 patients to this group to yield a review of 113 reported cases of neurenteric cysts. The most common reported location was cervical (63 cases), followed by thoracic (53 cases) and lumbosacral (27 cases). Junctional cysts were reported in both locations. There was a slight male predominance of 1.8:1 with the most common location of the cyst being intradural, extramedullary, and anterior or anterolateral to the cord. Although they found some case reports in their literature review of neurenteric cysts in association with other forms of OSD, the combination was infrequent. ${ }^{7,10,11,14,18,24,29,32,34,36,40,41,46,51,52}$

Our series of patients clearly differs from this profile. The cysts were most commonly located dorsal to the cord in the thoracolumbar region. In our series the presence of a neurenteric cyst was associated with another form of OSD in $69 \%$ of the cases. At least some form of abnormality accompanied the cyst in $92 \%$ of our patients. In other reviewed series, neurenteric cysts were associated with abnormalities in $12 \%$ (Arai, et al. ${ }^{4}$ ), 30\% (Agnoli, et al. $^{2}$ ), $43 \%$ (Wilkins and Odum ${ }^{53}$ ), and $54 \%$ (Holmes, et $\mathrm{al}^{22}$ ) of cases. In no previously reported series has the association between neurenteric cysts and other forms of OSD been so marked. The series most similar to ours was reported by Holmes, et al., ${ }^{22}$ in which they reviewed 26 pediatric patients in whom they noted a high percentage of associated abnormalities. Interestingly, they also reported that $70 \%$ of their cysts occupied a dorsal location to the cord, similar to our series. It is possible that the association of neurenteric cysts with spinal dysraphism may simply be underreported. Pang ${ }^{43}$ has noted that in his unreported series of neurenteric cysts, occurrence of associated SCMs are presented in $60 \%$ of the cases. Hoffman ${ }^{23}$ has similarly noted that in his unreported series of neurenteric cysts there is a nearly universal association with spinal dysraphism.

\section{Treatment Recommendations}

The surgical management of neurenteric cysts follows the general guidelines for other forms of OSD. Magnetic resonance imaging is helpful in predicting the complex anatomy of the cysts and their associated lesions. Anteriorly located cysts were well managed in this series via a posterior approach, but when feasible, an anterior approach to these lesions should be considered. Our $27 \%$ recurrence rate would suggest that the natural history of incompletely resected cysts is unfavorable and every attempt should be made to achieve a complete resection of the cyst and its wall at initial operation when technically feasible.

\section{References}

1. Abe K, Oyama K, Mori K, et al: Neurenteric cyst of the craniocervical junction--case report. Neurol Med Chir 39:875-880, 1999

2. Agnoli AL, Laun A, Schonmayr R: Enterogenous intraspinal cysts. J Neurosurg 61:834-840, 1984

3. Alrabeeah A, Gillis DA, Giacomantonio M, et al: Neurenteric cysts--a spectrum. J Pediatr Surg 23:752-754, 1988

4. Arai Y, Yamauchi Y, Tsuji T, et al: Spinal neurenteric cyst. Report of two cases and review of forty-one cases reported in Japan. Spine 17:1421-1424, 1992.

5. Beardmore HE, Wigglesworth FW: Vertebral anomalies and alimentary duplications. Clinical and embryological aspects. Peatr Clin North Am 5:457-474, 1958

6. Bentley JF, Smith JR: Developmental posterior enteric remnants and spinal malformations. The split notochord syndrome. Arch Dis Child 35:76-86, 1960

7. Birch BD, McCormick PC: High cervical split cord malformation and neurenteric cyst associated with congenital mirror movements: case report. Neurosurgery 38:813-815, 1996

8. Bremer JL: Dorsal intestinal fistula; accessory neurenteric canal: diastematomyelia. Archives of Path 54:132-138, 1952

9. Brooks BS, Duvall ER, el Gammal T, et al: Neuroimaging features of neurenteric cysts: analysis of nine cases and review of the literature. AJNR 14:735-746, 1993

10. Carachi R: The split notochord syndrome: a case report on a mixed spinal enterogenous cyst in a child with spina bifida cystica. Z Kinderchir 35:32-34, 1982 
11. Chang WH, Kak VK, Radotra BD, et al: Enterogenous cyst in the thoracic spinal canal in association with a syringomeningomyelocele. Childs Nerv Syst 8:105-107, 1992

12. D'Almeida AC, Stewart DH Jr: Neurenteric cyst: case report and review of the literature. Neurosurgery 8:596-598, 1981

13. Dias MS, Walker ML: The embryogenesis of complex dysraphic malformations: a disorder of gastrulation? Pediatr Neurosurg 18: 229-253, 1992

14. Ebisu T, Odake G, Fujimoto M, et al: Neurenteric cysts with meningomyelocele or meningocele. Split notochord syndrome. Childs Nerv Syst 6:465-467, 1990

15. Ellis AM, Taylor TK: Intravertebral spinal neurenteric cysts: a unique radiographic sign-"the hole-in-one vertebra". J Pediatr Orthop 17:766-768, 1997

16. Ergun R, Akdemir G, Gezici AR, et al: Craniocervical neurenteric cyst without associated abnormalities. Pediatr Neurosurg 32:95-99, 2000

17. Eynon-Lewis NJ, Kitchen N, Scaravilli F, et al: Neurenteric cyst of the cerebellopontine angle: case report. Neurosurgery 42:655-658, 1998

18. Freund M, Thale A, Hutzelmann A: Radiologic and histopathologic findings in a rare case of complex occult spinal dysraphism with association of a lumbar fibrolipoma, neurenteric cyst and tethered cord syndrome. Eur Radiol 8:624-627, 1998

19. Geremia GK, Russell EJ, Clasen RA: MR imaging characteristics of a neurenteric cyst. AJNR 9:978-980, 1988

20. Harriman DG: An intraspinal enterogenous cyst. J Pathol Bacteriol 75:415-419, 1959

21. Hes R: Neurenteric cyst or teratomatous cyst. J Neurosurg 80: 179-180, 1994 (Letter)

22. Holmes GL, Trader S, Ignatiadis P: Intraspinal enterogenous cysts. A case report and review of pediatric cases in the literature. Am J Dis Child 132:906-908, 1978

23. Hoffman HJ: Comment Neurosurgery 8:598-599, 1981

24. Kim CY, Wang KC, Choe G, et al: Neurenteric cyst: its various presentations. Childs Nerv Syst 15:333-341, 1999

25. Kincaid PK, Stanley P, Kovanlikaya A, et al: Coexistent neurenteric cyst and enterogenous cyst. Further support for a common embryologic error. Pediatr Radiol 29:539-541, 1999

26. Knight G, Griffiths T, Williams I: Gastrocytoma of the spinal cord. Br J Surg 42:635-638, 1955.

27. Kwok DM, Jeffreys RV: Intramedullary enterogenous cyst of the spinal cord. Case report. J Neurosurg 56:270-274, 1982

28. Lazareff JA, Hoil Parra JA: Intradural neurenteric cyst at the craniovertebral junction. Childs Nerv Syst 11:536-538, 1995

29. LeDoux MS, Faye-Petersen OM, Aronin PA, et al: Lumbosacral neurenteric cyst in an infant. Case report. J Neurosurg 78: 821-825, 1993

30. Lee SH, Dante SJ, Simeone FA, et al: Thoracic neurenteric cyst in an adult: case report. Neurosurgery 45:1239-1242, 1999

31. Macdonald RL, Schwartz ML, Lewis AJ: Neurenteric cyst located dorsal to the cervical spine: case report. Neurosurgery 28:583-587,1991

32. Mann KS, Khosla VK, Gulati DR, et al: Spinal neurenteric cyst. Association with vertebral anomalies, diastematomyelia, dorsal fistula, and lipoma. Surg Neurol 21:358-362, 1984

33. Matsushima T, Fukui M, Egami H: Epithelial cells in a socalled intraspinal neurenteric cyst: a light and electron microscopic study. Surg Neurol 24:656-660, 1985

34. Mendel E, Lese GB, Gonzalez-Gomez I, et al: Isolated lumbosacral neurenteric cyst with partial sacral agenesis: case report. Neurosurgery 35:1159-1162, 1994

35. Menezes AH, Ryken TC: Craniocervical intradural neurenteric cysts. Pediatr Neurosurg 22:88-95, 1995

36. Millis RR, Holmes AE: Enterogenous cyst of the spinal cord with associated intestinal reduplication, vertebral anomalies, and a dorsal dermal sinus. Case report. J Neurosurg 38:73-77, 1973

37. Miyagi K, Mukawa J, Mekaru S, et al: Enterogenous cyst in the cervical spinal canal. Case report. J Neurosurg 68:292-296, 1988

38. Mooney JF III, Hall JE, Emans JB, et al: Spinal deformity associated with neurenteric cysts in children. Spine 19:1445-1450, 1994

39. Morita Y, Kinoshita K, Wakisaka S, et al: Fine surface structure of an intraspinal neurenteric cyst: a scanning and transmission electron microscopy study. Neurosurgery 27:829-833, 1990

40. Odake G, Yamaki T, Naruse S: Neurenteric cyst with meningomyelocele. Case report. J Neurosurg 45:352-356, 1976

41. Page RE: Intraspinal enterogenous cyst associated with spondylolisthesis and spina bifida occulta. Report of a case. J Bone Joint Surg (Br) 56:541-544, 1974

42. Paleologos TS, Thom M, Thomas DG: Spinal neurenteric cysts without associated malformations. Are they the same as those presenting in spinal dysraphism? Br J Neurosurg 14:185-194, 2000

43. Pang D: Comment on High cervical split cord malformation and neurenteric cyst associated with congenital mirror movements: case report. Neurosurgery 38:815-816, 1996

44. Pang D, Dias MS, Ahab-Barmada M: Split cord malformation: Part I: A unified theory of embryogenesis for double spinal cord malformations. Neurosurgery 31:451-480, 1992

45. Prasad VS, Reddy DR, Murty JM: Cervico-thoracic neurenteric cyst: clinicoradiological correlation with embryogenesis. Childs Nerv Syst. 12:48-51, 1996

46. Puca A, Cioni B, Colosino C, et al: Spinal neurenteric cyst in association with syringomyelia: case report. Surg Neurol 37: 202-207, 1992

47. Rhaney K, Barclay GP: Enterogenous cysts and congenital diverticula of the alimentary canal with abnormalities of the vertebral column and spinal cord. J Path Bacteriol 77:457-471, 1959

48. Sampath S, Yasha TC, Shetty S, et al: Parasellar neurenteric cyst: unusual site and histology: case report. Neurosurgery 44: 1335-1337, 1999

49. van Landegem W, de Reuck J, de Waele L, et al: Enterogenous cyst of the cauda equina. A case report and a review of the literature. Clin Neurol Neurosurg 88:63-66, 1986

50. Weiss MA, Gebarski SS, McKeever PE: Foramen magnum neurenteric cyst causing mollaret meningitis: MR findings. AJNR 17:386-388, 1996

51. Whiting DM, Chou SM, Lanzieri CF, et al: Cervical neurenteric cyst associated with Klippel-Feil syndrome: a case report and review of the literature. Clin Neuropathol 10:285-90, 1991

52. Whitney RW, Brenner R, Gulati R: Occult diastematomyelia in adults--report of two cases. Clin Radiol 41:415-417, 1990

53. Wilkins RH, Odum GL: Spinal intradural cysts, in Vinken PJ, Bruyn GW (eds): Handbook of Clinical Neurology, Vol 20. Amsterdam: North Holland, 1976, pp 55-102

54. Wilkins RH, Rossitch JR: Intraspinal cysts, in Pang D (ed): Disorders of the Pediatric Spine. New York: Raven Press, 1995, pp 445-466

55. Zülch KJ: Histological Typing of Tumors of the Central Nervous System. Geneva: World Health Organization, 1979

Manuscript received December 4, 2000.

Accepted in final form December 20, 2000.

Address reprint requests to: Michael J. Rauzzino, M.D., Peninsula Neurosurgical Associates, 2102 Executive Drive, Hampton, Virginia 23666. email: mrauzzino@aol.com. 